\title{
ON THE RELATION BETWEEN THE KIRSCHNER AND POLENSKE VALUES FOR MARGARINES CONTAINING COCOANUT OR PALM KERNEL OILS.
}

\author{
By E. RICHARDS BOLTON, H. DROOP RICHMOND, \\ AND CECIL REVIS.
}

(Read at the Meeting, April 3, 1912.)

In a paper published last year (ANALYst, 1911, 36, 333), it was pointed out that the determination of the Kirschner value would enable the presence of small quantities of butter-fat to be estimated in the presence of cocoanut oil, and, further, that in itself it furnished a reliable figure for the percentage of cocoanut oil in the absence of butter-fat. The figures then given for the Kirschner values for mixtures containing no butter-fat fell practically on a straight line, but when the mixture contained butter-fat up to 10 per cent. a somewhat irregular curve was obtained. We have reinvestigated this point, and find that the irregularity was due to the fact that the values obtained for mixtures containing up to 15 per cent. of cocoanut oil were carried out with an Irish butter of very low Reichert-Meissl value (22), while the other values were obtained by using a butter of much higher Reichert-Meissl value (30) ; and we had not at that time recognised how sensitive to the presence of butter the Kirschner value was. We have therefore redetermined the values for those mixtures which contained the butter of low Reichert-Meissl value, with a butter of more normal figure, and are now able to make the following deductions :

1. That for the Kirschner values for both cocoanut and palm kernel oils (with or without admixture of butter-fat up to 10 per cent.) a straight line can be plotted which will represent, with very great closeness, the values experimentally obtained (see curves).

Further, for any percentage of cocoanut or palm kernel oils the difference in the Kirschner values for "no butter-fat" and for any percentage of butter-fat (up to 10 per cent.) will be proportional within very small limits to the percentage of butterfat; the closeness of the agreement indicates that the relation will also hold for higher percentages of butter-fat.

2. On examining the values obtained both for cocoanut and palm kernel oils, it was seen that the Polenske value was practically independent of the amount of butter-fat present, when present up to 10 per cent. in the mixture, and is practically dependent on the presence of the cocoanut or palm kernel oil only. The mean value was therefore calculated from the four values obtained for mixtures corresponding to each different percentage of cocoanut or palm kernel oil (see Table I.), and on plotting these mean values a regular curve was obtained. The following equations have been worked out for these " mean value" curves :

$$
\begin{aligned}
& x(\text { C.N.O. })=12.3(\mathrm{P}-0.45)^{0.747} ; \\
& x \text { (P.K.O. })=16.72(\mathrm{P}-0.45)^{0.806} ;
\end{aligned}
$$

where $x=$ the percentage of cocoanut or palm kernel oil. 
TABLE I.

\begin{tabular}{|c|c|c|c|c|c|c|}
\hline \multirow{2}{*}{ Cocoanut Oil. } & & & \multicolumn{4}{|c|}{ Butter-Fat. } \\
\hline & & & 0 per Cent. & 2 per Cent. & 5 per Cent. & 10 per Cent \\
\hline 0 per cent. & $\begin{array}{l}\text { Reichert-Meissl } \\
\text { Polenske ... } \\
\text { Kirschner... }\end{array}$ & $\begin{array}{l}\cdots \\
\cdots \\
\cdots\end{array}$ & $\begin{array}{l}0 \cdot 38 \\
0 \cdot 31 \\
0 \cdot 18\end{array}$ & $\begin{array}{l}0.92 \\
0.38 \\
0 \cdot 81\end{array}$ & $\begin{array}{l}1 \cdot 70 \\
0 \cdot 42 \\
1 \cdot 49\end{array}$ & $\begin{array}{l}3 \cdot 25 \\
0 \cdot 55 \\
2 \cdot 70\end{array}$ \\
\hline 5 per cent. & $\begin{array}{l}\text { Reichert-Meissl } \\
\text { Polenske ... } \\
\text { Kirschner ... }\end{array}$ & $\begin{array}{l}\cdots \\
\cdots \\
\cdots\end{array}$ & $\begin{array}{l}0.87 \\
0 \cdot 71 \\
0 \cdot 22\end{array}$ & $\begin{array}{l}1 \cdot 66 \\
0 \cdot 79 \\
0 \cdot 74\end{array}$ & $\begin{array}{l}2 \cdot 16 \\
0 \cdot 68 \\
1 \cdot 31\end{array}$ & $\begin{array}{l}4 \cdot 10 \\
0.93 \\
2 \cdot 85\end{array}$ \\
\hline 10 per cent. & $\begin{array}{l}\text { Reichert-Meissl } \\
\text { Polenske ... } \\
\text { Kirschner... }\end{array}$ & $\begin{array}{l}\cdots \\
\cdots \\
\cdots\end{array}$ & $\begin{array}{l}1 \cdot 64 \\
1 \cdot 17 \\
0 \cdot 32\end{array}$ & $\begin{array}{l}2 \cdot 39 \\
1 \cdot 20 \\
0 \cdot 88\end{array}$ & $\begin{array}{l}3 \cdot 40 \\
1 \cdot 37 \\
1 \cdot 58\end{array}$ & $\begin{array}{l}4 \cdot 86 \\
1 \cdot 26 \\
2 \cdot 99\end{array}$ \\
\hline 15 per cent. & $\begin{array}{l}\text { Reichert-Meissl } \\
\text { Polenske ... } \\
\text { Kirschner... }\end{array}$ & $\begin{array}{l}\cdots \\
\cdots \\
\cdots \\
\end{array}$ & $\begin{array}{l}2 \cdot 67 \\
1 \cdot 73 \\
0 \cdot 38\end{array}$ & $\begin{array}{l}3 \cdot 16 \\
1 \cdot 80 \\
0 \cdot 94\end{array}$ & $\begin{array}{l}4 \cdot 27 \\
1 \cdot 69 \\
1 \cdot 69\end{array}$ & $\begin{array}{l}5 \cdot 52 \\
2 \cdot 01 \\
2 \cdot 99\end{array}$ \\
\hline 25 per cent. & $\begin{array}{l}\text { Reichert-Meissl } \\
\text { Polenske ... } \\
\text { Kirschner ... }\end{array}$ & $\begin{array}{l}\cdots \\
\cdots \\
\cdots\end{array}$ & $\begin{array}{l}3 \cdot 91 \\
2 \cdot 91 \\
0 \cdot 54\end{array}$ & $\begin{array}{l}4 \cdot 85 \\
2 \cdot 61 \\
1 \cdot 15\end{array}$ & $\begin{array}{l}5 \cdot 53 \\
2 \cdot 96 \\
1 \cdot 94\end{array}$ & $\begin{array}{l}6 \cdot 54 \\
2 \cdot 93 \\
3 \cdot 08\end{array}$ \\
\hline 50 per cent. & $\begin{array}{l}\text { Reichert-Meissl } \\
\text { Polenske ... } \\
\text { Kirschner ... }\end{array}$ & $\begin{array}{l}\cdots \\
\cdots \\
\cdots\end{array}$ & $\begin{array}{l}6 \cdot 05 \\
7 \cdot 06 \\
1 \cdot 10\end{array}$ & $\begin{array}{l}6 \cdot 60 \\
7 \cdot 16 \\
1 \cdot 56\end{array}$ & $\begin{array}{l}7 \cdot 70 \\
6 \cdot 90 \\
2 \cdot 27\end{array}$ & $\begin{array}{l}9 \cdot 10 \\
7 \cdot 30 \\
3 \cdot 37\end{array}$ \\
\hline 75 per cent. & $\begin{array}{l}\text { Reichert-Meissl } \\
\text { Polenske ... } \\
\text { Kirschner ... }\end{array}$ & $\begin{array}{l}\cdots \\
\cdots \\
\cdots\end{array}$ & $\begin{array}{r}6 \cdot 97 \\
12 \cdot 36 \\
1 \cdot 50\end{array}$ & $\begin{array}{r}8 \cdot 34 \\
11 \cdot 91 \\
1.91\end{array}$ & $\begin{array}{r}9 \cdot 20 \\
12 \cdot 20 \\
2 \cdot 57\end{array}$ & $\begin{array}{r}10 \cdot 50 \\
12 \cdot 30 \\
3 \cdot 68\end{array}$ \\
\hline 100 per cent. & $\begin{array}{l}\text { Reichert-Meissl } \\
\text { Polenske ... } \\
\text { Kirschner... }\end{array}$ & $\begin{array}{l}\cdots \\
\cdots \\
\cdots\end{array}$ & $\begin{array}{r}8 \cdot 08 \\
16 \cdot 02 \\
2 \cdot 01\end{array}$ & $\overline{-}$ & - & - \\
\hline
\end{tabular}

These relations show that the influence on the Polenske figure of 1 per cent. of cocoanut oil is the same as that of about 1.75 per cent. of palm kernel oil. The figures obtained from the equations for palm kernel oil are almost identical with the experimental figures, but the agreement is not quite so good in the case of cocoanut oil, and we have not taken into account the value for 100 per cent. in calculating the equation to this curve. The values in the latter case show somewhat irregular fluctuations, which are probably due to the distillation of the volatile insoluble acids in cocoanut oil, on account of their lower molecular weight than those of palm kernel oil, being more influenced by the other constituents of the mixture. The chief difference is in the value for cocoanut oil itself, the experimental value being 16.5 as against 17.05 calculated from the formula. We are, after many experiments, of the 
opinion that it is not possible to obtain the true value for cocoanut oil in the ordinary apparatus, and this point will be referred to later.

We therefore point out that the Polenske value acts as an "indicator," so that, when a margarine containing cocoanut or palm kernel oils is examined by the Reichert-Meissl-Polenske-Kirschner process, reference to this mean curve at once determines the percentage of cocoanut or palm kernel oil apart from other values. The corresponding Kirschner value obtained from the typical curve then determines the presence or absence of butter-fat, the Reichert-Meissl value acting as a confirmatory figure, and controlling the small fluctuations which may occur in the Kirschner value occasioned by a variation in butyric acid content of different butters.

The tables (II. and III.) here given for cocoanut and palm kernel oils, with and without admixture of butter-fat, are the typical values obtained from the curves which are also given, and we feel that they will prove a reliable guide provided that the method be carried out under standard conditions laid down in the paper previously referred to, the standard apparatus being also employed (ANALYST, 1904, 29, 155).

On account of the similarity of the results obtained for cocoanut and palm kernel oil, the following formula will give the percentage of butter present with either fat for the Kirschner and Polenske values found experimentally:

$$
\text { Butter per cent. }=\frac{\mathrm{K}-\left(0.262 \mathrm{P}^{0 \cdot 63}+0.09\right)}{0.242} ; *
$$

or nearly as exactly by the more simple formula :

$$
\text { Butter per cent. } \frac{K-(0 \cdot 1 \mathrm{P}+0 \cdot 24)}{0.244 .}
$$

The following formulæ connect the Kirschner value and percentage of butter-fat when neither cocoanut nor palm kernel oil is present :

$\mathrm{K}=0.236 \mathrm{~B}+0.33$, or, with a small increase in the probable error, $\mathrm{K}=0.244 \mathrm{~B}$ +0.28 , which is practically the formula given above.

Exception may be taken to the above formulæ, on the ground that it supposes a certain fixed value for the butyric acid content of the butter present. While this is undoubtedly true, the variations so caused will not in the vast majority of cases lead to errors of any great magnitude, and the percentage of butter determined by the formula has usually been within 0.5 per cent. of that actually present.

We think it necessary to draw attention to an observation we have made recently. In the standard apparatus, that portion of the still-head which passes through the cork and into the interior of the distillation flask is provided with a small hole in the side to prevent the collection of condensed liquid in the still-head.

$\begin{array}{ccccc}\text { *Values of }(0.262 & \left.\mathrm{P}^{0.63}+0.09\right): & \\ \text { P. } & & & & \text { Value. } \\ 0.5 & \ldots & \ldots & \ldots & 0.26 \\ 1 & \ldots & \ldots & \ldots & 0.35 \\ 2 & \ldots & \ldots & . . & 0.50 \\ 3 & \ldots & \ldots & \ldots & 0.61 \\ 4 & \ldots & \ldots & \ldots & 0.72 \\ 5 & \ldots & \ldots & \ldots & 0.81 \\ 6 & \ldots & \ldots & \ldots & 0.90 \\ 7 & \ldots & \ldots & \ldots & 0.98\end{array}$

$\begin{array}{rrrrr}\text { P. } & & & & \text { value. } \\ 8 & \ldots & \ldots & \ldots & 1.06 \\ 9 & \ldots & \ldots & \ldots & 1.13 \\ 10 & \ldots & \ldots & \ldots & 1.21 \\ 11 & \ldots & \ldots & \ldots & 1.28 \\ 12 & \ldots & \ldots & \ldots & 1.34 \\ 13 & \ldots & \ldots & \ldots & 1.41 \\ 14 & \ldots & \ldots & \ldots & 1.47 \\ 15 & \ldots & \ldots & \ldots & 1.53\end{array}$


As originally designed by Polenske, this hole had a fixed distance from the stopper of the flask. Insufficient attention is paid to this point by makers of the apparatus, and we have found that if the hole is much more than $1 \mathrm{~cm}$. from the lower surface of the cork, low Polenske values may be obtained with high percentages of cocoanut oil ; and we think that if this method be made a standard one, particular attention should be given to this point.

TABLE II.

\begin{tabular}{|c|c|c|c|c|c|c|}
\hline \multirow{2}{*}{ Cocoanut Oil. } & \multirow{2}{*}{$\begin{array}{l}\text { Polenske } \\
\text { Indicator } \\
\text { Value. }\end{array}$} & & \multicolumn{4}{|c|}{ Butter-Fat. } \\
\hline & & & $\begin{array}{l}0 \text { per } \\
\text { Cent. }\end{array}$ & $\begin{array}{l}2 \text { per } \\
\text { Cent. }\end{array}$ & $\begin{array}{c}5 \text { per } \\
\text { Cent. }\end{array}$ & $\begin{array}{l}10 \text { per } \\
\text { Cent. }\end{array}$ \\
\hline 0 per cent. & $0.45 \quad\{$ & $\begin{array}{l}\text { Kirschner } \\
\text { Reichert-Meissl } \ldots\end{array}$ & $\begin{array}{l}0 \cdot 18 \\
0 \cdot 38\end{array}$ & $\begin{array}{l}0 \cdot 80 \\
0.92\end{array}$ & $\begin{array}{l}1 \cdot 49 \\
1 \cdot 70\end{array}$ & $\begin{array}{l}2 \cdot 70 \\
3 \cdot 25\end{array}$ \\
\hline 5 per cent. & $0 \cdot 76\{$ & $\begin{array}{ll}\text { Kirschner } & \ldots \\
\text { Reichert-Meissl ... }\end{array}$ & $\begin{array}{l}0.25 \\
0.87\end{array}$ & $\begin{array}{l}0 \cdot 75 \\
1.65\end{array}$ & $\begin{array}{l}1 \cdot 55 \\
2 \cdot 15\end{array}$ & $\begin{array}{l}2 \cdot 82 \\
4 \cdot 10\end{array}$ \\
\hline 10 per cent. & $1 \cdot 22\{$ & $\begin{array}{ll}\text { Kirschner } & \ldots \\
\text { Reichert-Meissl } & \ldots\end{array}$ & $\begin{array}{l}0 \cdot 34 \\
1 \cdot 60\end{array}$ & $\begin{array}{l}0 \cdot 84 \\
2 \cdot 45\end{array}$ & $\begin{array}{l}1 \cdot 60 \\
3 \cdot 42\end{array}$ & $\begin{array}{l}2 \cdot 90 \\
4 \cdot 90\end{array}$ \\
\hline 15 per cent. & $1 \cdot 75\{$ & $\begin{array}{ll}\text { Kirschner } & \ldots \\
\text { Reichert-Meissl } & \ldots\end{array}$ & $\begin{array}{l}0 \cdot 42 \\
2 \cdot 52\end{array}$ & $\begin{array}{l}0 \cdot 92 \\
3 \cdot 15\end{array}$ & $\begin{array}{l}1 \cdot 68 \\
4 \cdot 35\end{array}$ & $\begin{array}{l}2 \cdot 96 \\
5 \cdot 55\end{array}$ \\
\hline 25 per cent. & $2 \cdot 91 \quad$ & $\begin{array}{ll}\text { Kirschner } & \ldots \\
\text { Reichert-Meissl } \ldots\end{array}$ & $\begin{array}{l}0 \cdot 60 \\
3.92\end{array}$ & $\begin{array}{l}1.08 \\
4.57\end{array}$ & $\begin{array}{l}1 \cdot 82 \\
5 \cdot 55\end{array}$ & $\begin{array}{l}3.08 \\
6.55\end{array}$ \\
\hline 50 per cent. & $7 \cdot 10\{$ & $\begin{array}{ll}\text { Kirschner } & \ldots \\
\text { Reichert-Meissl } & \ldots\end{array}$ & $\begin{array}{l}1 \cdot 02 \\
6 \cdot 05\end{array}$ & $\begin{array}{l}1 \cdot 50 \\
6 \cdot 88\end{array}$ & $\begin{array}{l}2 \cdot 20 \\
7 \cdot 72\end{array}$ & $\begin{array}{l}3 \cdot 38 \\
8 \cdot 95\end{array}$ \\
\hline 75 per cent. & $12 \cdot 19\{$ & $\begin{array}{ll}\text { Kirschner } & \ldots \\
\text { Reichert-Meissl } & \ldots\end{array}$ & $\begin{array}{l}1 \cdot 45 \\
7 \cdot 00\end{array}$ & $\begin{array}{l}1 \cdot 92 \\
8 \cdot 35\end{array}$ & $\begin{array}{l}2 \cdot 55 \\
9 \cdot 20\end{array}$ & $\begin{array}{r}3 \cdot 70 \\
10 \cdot 50\end{array}$ \\
\hline 100 per cent. & 16.5\{ & $\begin{array}{ll}\text { Kirschner } & \ldots \\
\text { Reichert-Meissl } & \ldots\end{array}$ & $\begin{array}{l}1 \cdot 88 \\
8 \cdot 08\end{array}$ & - & - & - \\
\hline
\end{tabular}

The Relation between the Kirschner and Polenske Values for Butter-Fat.

As the Kirschner value for butter is almost entirely obtained from the butyric acid present, it is evident that a relation between the Polenske value and the Kirschner value will be more sensitive than the relation, at present accepted, between the Reichert-Meissl and Polenske values. We tentatively put forward the following table with the hope that other workers will criticise or verify the figures:

$\begin{array}{cccccccc}\begin{array}{c}\text { Kirschner } \\ \text { Value. }\end{array} & & & & & & & \\ 20 & \ldots & \ldots & \ldots & \ldots & \ldots & \ldots & \begin{array}{c}\text { Polenske } \\ \text { Value. }\end{array} \\ 22 & \ldots & \ldots & \ldots & \ldots & \ldots & \ldots & 2 \cdot 10 \\ 24 & \ldots & \ldots & \ldots & \ldots & \ldots & \ldots & 2 \cdot 65 \\ 26 & \ldots & \ldots & \ldots & \ldots & \ldots & \ldots & 3 \cdot 20\end{array}$




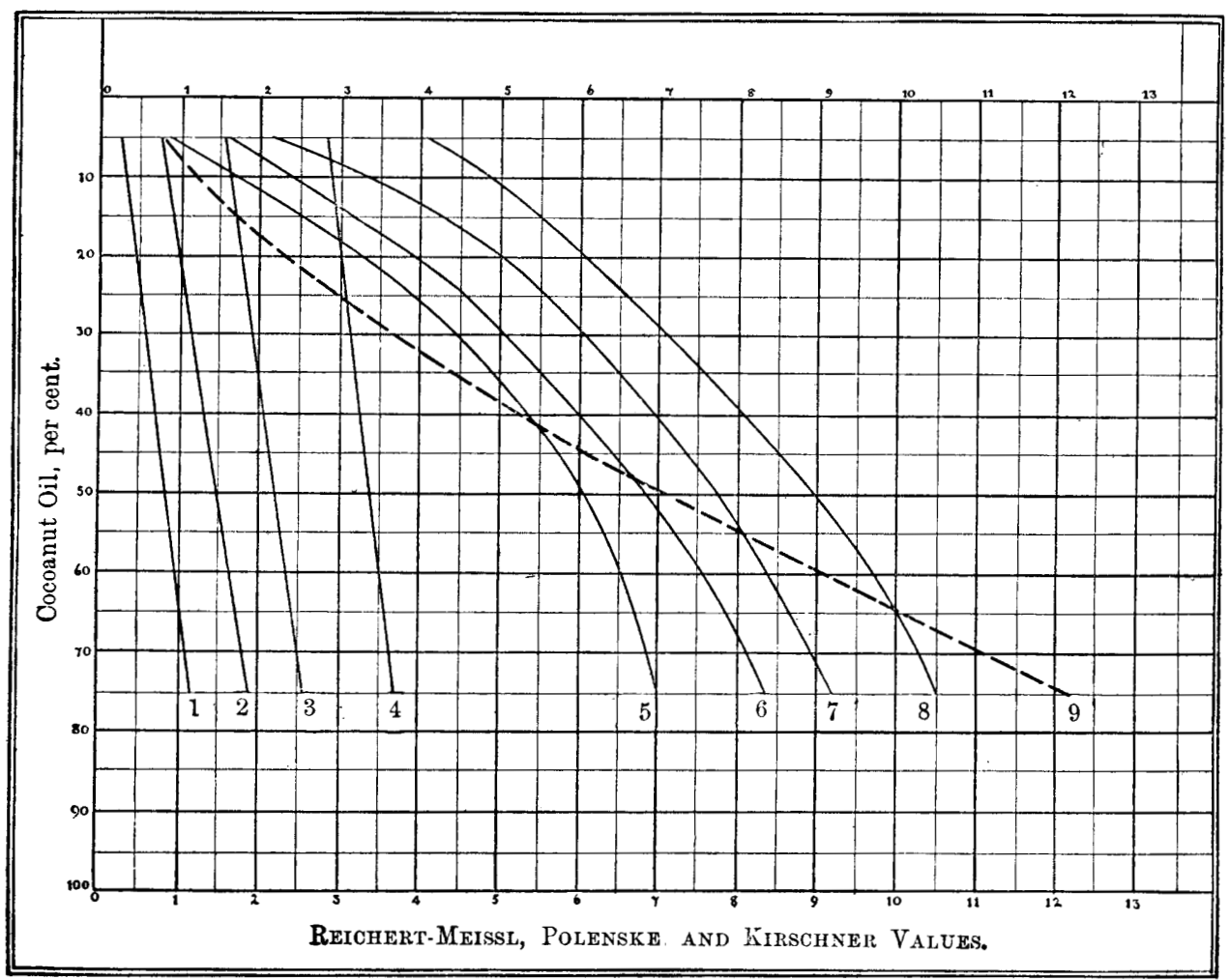

1. Kirschner, 0 per cent. butter. 4 . Kirschner, 10 per cent. butter. $\mid$ 7. R.-M., 5 per cent. butter.
2.
5. R.-M., 0 per cent. butter.
8. , $10,,$,
3.
6.
Mean Polenske.

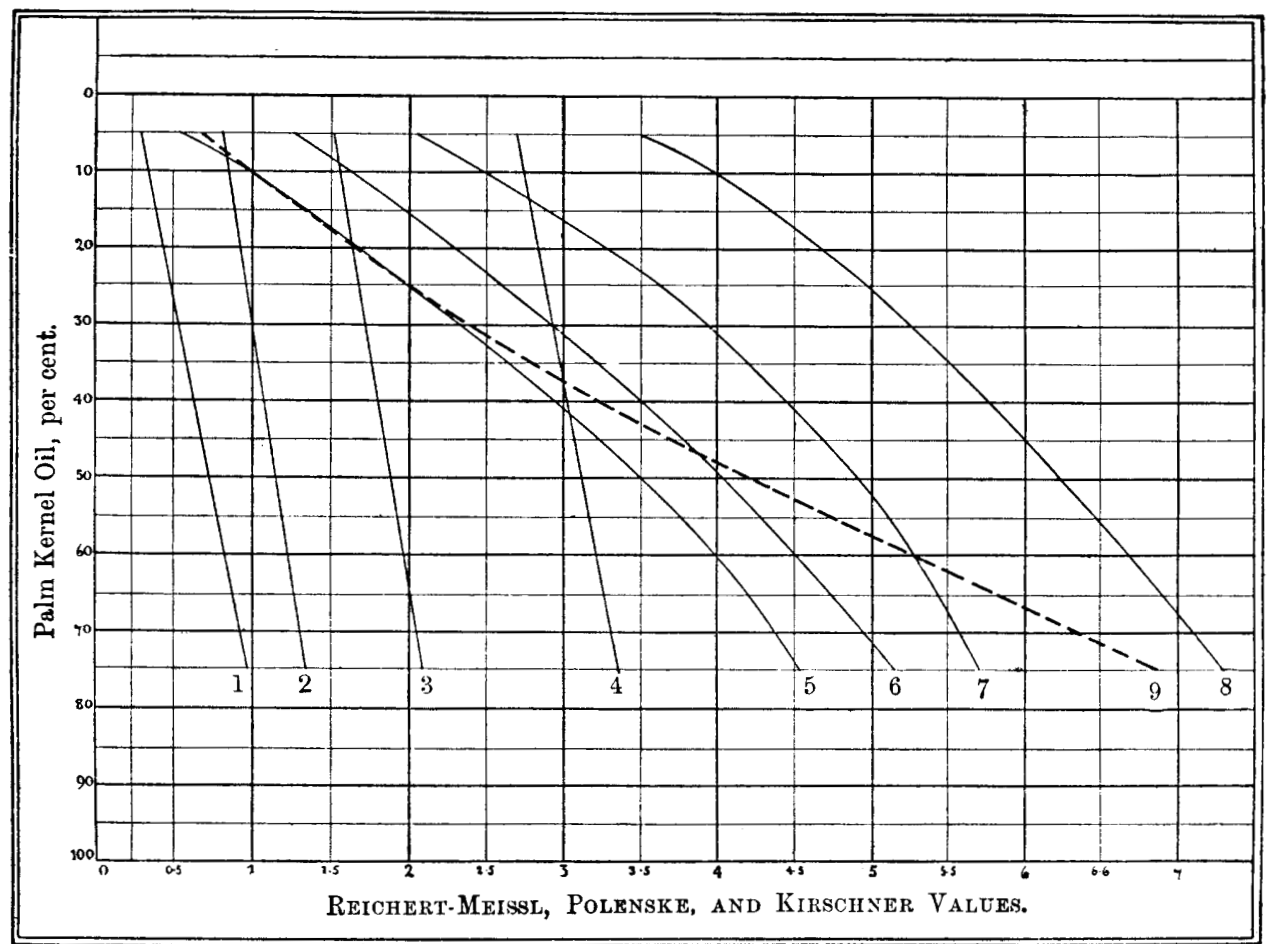

1. Kirschner, 0 per cent. butter.

$\begin{array}{llll}2 . & 2 & 2 & \text {, }\end{array}$
4. Kirschner, 10 per cent. butter. 5. R.-M., 0 per cent. butter.

6. , 2 ,,
7. R.-M., 5 per cent. butter.

8. R. -M., 10 per cent.

9. Mean Polenske. 


\section{KIRSCHNER AND POLENSKE VALUES FOR MARGARINES, ETC.}

A variation of \pm 1 must be allowed in the Polenske value corresponding to any particular Kirschner value, but it would appear that less than 5 per cent. of cocoanut oil will cause the Polenske value to fall outside this limit, except in those cases in which cows have been specially fed for the purpose of upsetting the Polenske process. In conclusion we desire to express our thanks to Messrs. G. A. Payne and $H$. R. Burnett for carrying out the experimental part of the investigation.

TABLE III.

\begin{tabular}{|c|c|c|c|c|c|c|}
\hline \multirow{2}{*}{$\begin{array}{l}\text { Palm Kernel } \\
\text { Oil. }\end{array}$} & \multirow{2}{*}{$\begin{array}{l}\text { Polenske } \\
\text { Indicator } \\
\text { Value. }\end{array}$} & & \multicolumn{4}{|c|}{ Butter-Fat. } \\
\hline & & & $\begin{array}{l}0 \text { per } \\
\text { Cent. }\end{array}$ & $\begin{array}{l}2 \text { per } \\
\text { Cent. }\end{array}$ & $\begin{array}{l}5 \text { per } \\
\text { Cent. }\end{array}$ & $\begin{array}{l}10 \text { per } \\
\text { Cent. }\end{array}$ \\
\hline 0 per cent. & 0.45\{ & $\begin{array}{ll}\text { Kirschner } & \ldots \\
\text { Reichert-Meissl } & \ldots\end{array}$ & $\begin{array}{l}0 \cdot 18 \\
0 \cdot 38\end{array}$ & $\begin{array}{l}0.80 \\
0.92\end{array}$ & $\begin{array}{l}1 \cdot 49 \\
1 \cdot 70\end{array}$ & $\begin{array}{l}2 \cdot 70 \\
3 \cdot 25\end{array}$ \\
\hline 5 per cent. & 0.68\{ & $\begin{array}{ll}\text { Kirschner } & \ldots \\
\text { Reichert-Meissl } & \ldots\end{array}$ & $\begin{array}{l}0.30 \\
0.53\end{array}$ & $\begin{array}{l}0 \cdot 80 \\
1 \cdot 27\end{array}$ & $\begin{array}{l}1.51 \\
2.05\end{array}$ & $\begin{array}{l}2 \cdot 70 \\
3.50\end{array}$ \\
\hline 10 per cent. & $1 \cdot 00\{$ & $\begin{array}{ll}\text { Kirschner } & \ldots \\
\text { Reichert-Meissl } & \ldots\end{array}$ & $\begin{array}{l}0 \cdot 35 \\
1 \cdot 00\end{array}$ & $\begin{array}{l}0 \cdot 85 \\
1 \cdot 62\end{array}$ & $\begin{array}{l}1.54 \\
2.50\end{array}$ & $\begin{array}{l}2 \cdot 75 \\
4 \cdot 00\end{array}$ \\
\hline 15 per cent. & $1 \cdot 35\{$ & $\begin{array}{ll}\text { Kirschner } & \ldots \\
\text { Reichert-Meissl ... }\end{array}$ & $\begin{array}{l}0 \cdot 40 \\
1 \cdot 35\end{array}$ & $\begin{array}{l}0 \cdot 90 \\
2 \cdot 00\end{array}$ & $\begin{array}{l}1 \cdot 57 \\
2 \cdot 90\end{array}$ & $\begin{array}{l}2 \cdot 80 \\
4 \cdot 35\end{array}$ \\
\hline 25 per cent. & 1.97\{ & $\begin{array}{ll}\text { Kirschner } & \ldots \\
\text { Reichert-Meissl ... }\end{array}$ & $\begin{array}{l}0.48 \\
1.97\end{array}$ & $\begin{array}{l}0 \cdot 97 \\
2 \cdot 60\end{array}$ & $\begin{array}{l}1 \cdot 65 \\
3 \cdot 62\end{array}$ & $\begin{array}{l}2 \cdot 87 \\
4 \cdot 97\end{array}$ \\
\hline 50 per cent. & $4 \cdot 22\{$ & $\begin{array}{l}\text { Kirschner } \\
\text { Reichert-Meissl ... }\end{array}$ & $\begin{array}{l}0 \cdot 72 \\
3 \cdot 50\end{array}$ & $\begin{array}{l}1 \cdot 16 \\
4 \cdot 05\end{array}$ & $\begin{array}{l}1 \cdot 87 \\
4.92\end{array}$ & $\begin{array}{l}3 \cdot 12 \\
6 \cdot 22\end{array}$ \\
\hline 75 per cent. & $6 \cdot 87\{$ & $\begin{array}{ll}\text { Kirschner } & \ldots \\
\text { Reichert-Meissl ... }\end{array}$ & $\begin{array}{l}0 \cdot 97 \\
4.55\end{array}$ & $\begin{array}{l}1 \cdot 35 \\
5 \cdot 15\end{array}$ & $\begin{array}{l}2 \cdot 07 \\
5 \cdot 70\end{array}$ & $\begin{array}{l}3 \cdot 35 \\
7 \cdot 30\end{array}$ \\
\hline 100 per cent. & $9 \cdot 82\{$ & $\begin{array}{ll}\text { Kirschner } & \ldots \\
\text { Reichert-Meissl } & \ldots\end{array}$ & $\begin{array}{l}1 \cdot 07 \\
5 \cdot 22\end{array}$ & - & - & - \\
\hline
\end{tabular}

\section{Discussion.}

Mr. W. BACON asked whether, in the form of apparatus with a very large distilling tube, this tube was insulated by some non-conducting material? If not, since the tube was so close to the neck of the flask, a great deal of condensation would be likely to occur.

Mr. E. M. Hawkins asked whether, in a mixture consisting of cocoanut oil and of butter, of which the Kirschner figure was known, it would be possible, from the Polenske and Kirschner figures, to determine with a fair degree of certainty the proportion of cocoanut oil ?

Mr. Revis said that with the special tube described there was no condensation 
at all, the distillation being, as a matter of fact, more rapid than with the ordinary form. He should like once again to emphasise the importance of always using the same standard pattern of apparatus. The exact details did not matter, provided they were the same in every case. If that were so, the results obtained by different workers would agree, and the results obtained by each would be consistent and concordant among themselves. They (the authors) had found that the Polenske, ReichertMeissl and Kirschner processes were all three quite as accurate and definite as an ordinary titration of acid and alkali. The question asked by Mr. Hawkins as to cocoanut oil and butter mixtures involved some difficulty, because butter varied so greatly as regards its proportion of butyric acid. As they had pointed out, a much more sensitive relationship was shown between cocoanut oil and butter fat when the Kirschner and Polenske figures were used than when the Reichert-Meissl and Polenske figures were used. They put forward their results quite tentatively, but believed the process to be capable of showing the presence of as little as 3 per cent. of cocoanut oil in butter fat. There must always be some doubt as to the exact quantity of butter fat present in a mixture, because of the varying nature of the butter itself.

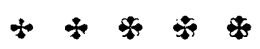

